\title{
On the Relationship between Fertility, Development and Gender Equality: A Comparison of Western and MENA Countries
}

\author{
Zafer Buyukkececi, Henriette Engelhardt
}

\begin{abstract}
The changing macro-level relationship between fertility and development (i.e., the standard of living, health and education) from negative to positive for the most advanced economies has received considerable attention recently. Using aggregate data, we compare the relationship between fertility and development in Western countries with the Middle East and North Africa (MENA) region, where fertility rates are higher than in other regions with identical levels of development. To understand the drivers of this association, we further link fertility to the components of development as well as female labour force participation separately. Our findings show that fertility and development were positively associated for only a short period in Western countries and that the relationship turned negative again in recent years. Recent data also show that there is no significant relationship between fertility and development in MENA countries. These findings indicate that the wellacknowledged theories of fertility and development do not apply in every context.
\end{abstract}

Keywords: Fertility $\cdot$ Human Development Index $\cdot$ MENA region

\section{Introduction}

Seminal demographic literature, such as on the first and second demographic transition theories, have postulated a negative relationship between fertility and development (Kirk 1996; Lesthaeghe 2010). To explain this negative association between fertility and development, mechanisms such as declining mortality and increasing child survival (Notestein 1945), investment in the quality rather than quantity of children and opportunity costs of motherhood in conflict with female employment (Becker 1960) have been proposed.

One recognized mechanism used to explain the fertility-development nexus is gender equality, which has been highlighted as a necessary condition for "the transition from very high fertility to fertility around replacement level" (McDonald 2000b: 432). More recently, however, new theoretical considerations suggest that 
the established negative correlation between fertility and development has turned positive for the most advanced economies (Anderson/Kohler 2015; Goldscheider et al. 2015). Rising levels of gender equality with development are emphasized as the potential driver of the emerging positive association between fertility and development (Esping-Andersen/Billari 2015; McDonald 2000a/b). This is empirically supported by Myrskylä et al. (2009), who, in their study published in Nature, found that the relationship between the Human Development Index (HDI) and total fertility rate (TFR) reverses from negative to positive at advanced HDI levels. Although these findings are consistent with theoretical expectations suggesting a reversal of the relationship between fertility and development from negative to positive due to advanced levels of gender equality, it remains unclear whether the observed association is actually driven by gender equality or other factors, including progress in living standards, education and health.

Moreover, these theories and empirical assessments have focused mainly on Western countries (e.g., Anderson/Kohler 2015; Fox et al. 2019; Luci-Greulich/ Thévenon 2014; Myrskylä et al. 2009, 2011). Yet the evolutionary process of social change can be modified by cultural and institutional context and is not the same across all societies (McDonald 1994; McNicoll 1980). Countries of the Middle East and North Africa (MENA), for instance, showed considerable improvements in economic standard of living, education and health, which comprise the three main indicators of development. Despite the development progress, the region falls considerably short of indicators of gender equality such as women's labour force participation and political empowerment (World Bank 2004), contrary to theoretical expectations and empirical evidence for other countries (Forsythe et al. 2000; Inglehart/Norris 2003). According to the World Economic Forum (2017), the MENA region globally ranks last in terms of gender equality with an average remaining gender gap of 40 percent. At the same time, the demographic patterns suggested by the demographic transition theory are not followed by all countries and some countries such as Algeria, Egypt and Lebanon have actually experienced an increase in fertility rates in recent years (Engelhardt et al. 2018), although these countries have made significant progress toward development. Moreover, evidence indicates that MENA countries have higher fertility rates than would be the case in other countries at identical levels of development and the fertility-development link is weaker in MENA countries (Tabutin/Schoumaker 2005). This asserts that fertility and development trends in the MENA region may be different from Western countries and what established theories suggest.

In this study, we examine how the fertility-development relationship has evolved over time in MENA countries and compare it to the relationships in Western countries. We also separately assess how the three components - living standards, education and health - of development, as well as female labour force participation ${ }^{1}$ as an indicator of gender equality are related to fertility in these two contexts to test

1 Similar to the previous studies (e.g., Luci-Greulich/Thévenon (2014), female labour force participation has been used as an indicator of gender equality in our analyses. 
the relevance of each component of development as well as gender equality. Our study contributes to the literature in two regards.

First, we test the importance of development for fertility in two contexts with substantially different levels and progress in gender equality and fertility: MENA countries with the lowest levels of gender equality and relatively high levels of development and Western countries with advanced levels of gender equality and development. Given the relevance of gender equality to the fertility-development nexus as suggested by theoretical arguments (Anderson/Kohler 2015; EspingAndersen/Billari 2015; Goldscheider et al. 2015; McDonald 2000b), these two contexts might have different fertility-development patterns. We test this by comparing how the correlation between fertility and development differs between Western and MENA countries.

Second, we revisit the relationship between fertility and development in advanced economies. Harttgen and Vollmer (2014) showed that the reversal in the TFR-HDI relationship found by Myrskylä et al. (2009) is not robust for the UNDP revision of the HDI calculation method. Using more recent data, we test whether a reversal from negative to positive exists between TFR and HDI.

We combine Human Development Index datasets (HDI; UNDP 2019), which contain information on various development indicators with datasets from the World Development Indicators (WDI; World Bank 2018), which contain annual information on fertility. We first estimate the time-series association between fertility and development (or its components and female labour force participation) while controlling for country-specific fixed effects. Second, we apply the differencein-differences strategy of Myrskylä et al. (2009) to examine the overall relationship between fertility and development.

\section{Fertility, Development and Gender Equality}

\section{Western countries}

In the historical decline in fertility, the key pre-transitional factor was mortality, especially infant mortality (Davis 1945; Mason 1997). Western countries have achieved remarkable reductions in mortality rates with rising incomes, urbanization and industrialization. For instance, evidence from four European countries shows that whilst infant mortality rates ranged from 100 deaths per 1,000 live births in the late $19^{\text {th }}$ century, by the 1950 s they ranged from 20 to 50 deaths per 1,000 live births (Corsini/Viazzo 1993). Subsequently, the decline in mortality led to a shift from a high to a low fertility regime between the late $19^{\text {th }}$ to the early $20^{\text {th }}$ century. Over the course of the demographic transition, Europe's distinct past characterized by Malthusian cycles that emphasize a positive fertility-economic growth link started breaking down with the exception of the baby boom as a period when development was accompanied by a rise in fertility (Caldwe/l 1982; Guinnane 2011). Recent research, indeed, has empirically confirmed the importance of childhood 
survivorship in childbearing decisions (Reher et al. 2017). Mortality has not only influenced childbearing decisions, but also the timing and prevalence of marriage.

Although "truly modern demographic behaviour could not begin before childhood mortality declined to insignificant levels" (Reher 2021: 4), mortality alone does not explain the shift from very high to very low fertility rates. Many other factors, such as the gender revolution (Goldin 2006), the interaction between women's labour force participation and the lack of institutional adjustment, cultural and ideological innovations that led to greater behavioural freedom (Lesthaeghe 1983) and more individualistic attitudes (Van De Kaa 1987), have attracted the attention of scholars.

In the 20-30 years that followed the end of the baby boom, Western countries experienced rapid social and cultural changes. The trend converged in most advanced countries, albeit with visible differences in timing, tempo and degree accompanied by rapid economic growth. For instance, the shift away from the male breadwinner model had begun in the 1960s and accelerated in the 1970s in Scandinavia and North America, whereas similar transitions in countries like West Germany and Spain occurred with a delay of one or two decades (Esping-Andersen 2009). Reher (2021) emphasized the historical baggage of societies that drives these differences. The key determinants of historical baggage were the relative importance of the individual, family and religion in society (Derosas/van Poppe/ 2006; Inglehart/ Baker 2000; Reher 1998).

These progressive tendencies clashed with norms shaped by the regime of male breadwinner/female housewife. Neither the status nor the bargaining power of women increased at the same pace, despite their non-negligible involvement in the economy (Goldin 1990). Consequently, a conflict arose between individual-oriented social institutions with a high degree of gender equality and family-oriented social institutions with persistent gender inequality, resulting in very low fertility among Western countries (McDonald 2000a/b). Having children and starting a family was associated with child-rearing, domestic work and male breadwinner roles. This in turn was perceived as a barrier to women's careers. The marketable skills of men and women began to converge as women became more involved in the economy. As a result, the cost of childbearing for women increased substantially, which reduced the returns of marriage (Becker 1974). Subsequently, new ways of living together such as cohabitation started emerging, whereas partnerships became less stable and fertility declined (Lesthaeghe 2010).

Rising levels of development and gender equality were paralleled by fertility decreases in societies with high levels of gender inequality. Most Western countries had low fertility rates at the end of the $20^{\text {th }}$ century with some exceptions such as France where fertility rates remained relatively high, despite low levels of gender inequality (Population Reference Bureau 2007). Yet Rindfuss and Brewster (1996) argued that changes in the social organization of work and childcare arrangements would alter these trends and that easing women's conflicts in balancing work and family life courses would lead to an increase in fertility. Similarly, McDonald (2000b) pointed to a reversal of the macro relationship between fertility and gender equality in the long run. He argued that institutions would develop reforms that support rising fertility at advanced levels of gender equality. This is more recently supported 
by Esping-Andersen and Billari (2015) who suggested that the declines in fertility with the increasing number of women involved in the economy would be reversed as societies approach gender egalitarianism. Increasing gender equality at both institutional and household levels would allow individuals to have their desired number of children while ensuring the reconciliation of work and family life courses (Anderson/Kohler 2015; Myrskylä et al. 2011). Goldscheider et al. (2015) further emphasized the male involvement in family life for reversing fertility trends. In line with these theoretical expectations, the focus of family policies in many Western countries has shifted to the expansion of parental leave for both men and women and the provision of childcare that aimed at reducing work-family conflicts.

Several studies supported these recent theories suggesting a reversal/U-shaped pattern for the relationship between fertility and development empirically. Myrskylä et al. (2009) showed that the relationship between development and fertility reverses from negative to positive after a certain threshold. In the same vein, Luci-Greulich and Thévenon (2014) found a change in the relationship between fertility and GDP per capita above a certain threshold of economic development for 30 OECD countries. Moreover, by decomposing GDP per capita into several components, they identified female employment as a co-varying factor in the fertility rebound. This conclusion is consistent with theoretical expectations (Anderson/Kohler 2015; Esping-Andersen/ Billari 2015; Goldscheider et al. 2015; McDonald 2000a/b; Myrskylä et al. 2011; Rindfuss/Brewster 1996): Countries with high levels of development as measured by health, income and education, but low levels of gender equality, continue to experience declining fertility.

Empirical findings on the relationship between fertility, development and gender equality, however, are not entirely consistent. Furuoka (2009) found a negative association between fertility and development in countries with lower levels of development, whereas the relationship remained negative, albeit weak, in countries with a high HDI. In the same vein, Harttgen and Vollmer (2014) found no evidence for the inverse $\mathrm{J}$-shaped association using the recent revision of the HDI calculation. By utilizing gender equality, Kolk (2019) examined the influence of gender equality on fertility in 35 developed countries. The results showed that a U-shaped pattern was only observed across countries and that changes within countries did not lead to a reversal of fertility and gender equality.

\section{MENA countries}

In contrast to Western countries, mortality in MENA countries was very high in the first half of the $20^{\text {th }}$ century. Crude death rates were close to 25 percent and life expectancy was about 40 years until the 1950s. In the same vein, fertility rates were very high, reaching seven or eight children per woman. In the second half of the $20^{\text {th }}$ century, mortality in the MENA countries was significantly reduced. Infant mortality rates fell from about 200 deaths per 1,000 live births in the 1950s to less than 50 deaths per 1,000 live births by the end of the century (Roudi 2001) reaching levels that Western countries had half a decade ago. Along with the decline in mortality, fertility fell to below six and five in the 1980s and 1990s, respectively and then to 
3.1 in the early 2000s (World Bank 2017). Nevertheless, these rates were still higher than the average fertility rates that developed countries had in the 1950s (i.e., 2.8; World Bank 2018).

The fertility decline occurred late in comparison to other regions and concealed diversity in the pace of change between countries and sub-regions. For instance, in 2016, Saudi Arabia had a total fertility rate of 2.4, whereas women in Jordan had 3.5 children on average (World Bank 2017). Tabutin and Schoumaker (2005) further showed that the relationship between fertility and development is very weak. At same HDI level, total fertility rates ranged from 2.0 in Tunisia to 4.1 in Saudi Arabia. Moreover, fertility in many MENA countries is significantly higher than it would be elsewhere at the same level of development.

While the rapid decline in fertility in MENA countries is not negligible, fertility in several countries such as Jordan, Morocco, Syria and Tunisia has stabilized since the mid-2000s (Be/ Air 2017). Some countries such as Algeria and Egypt even experienced an increase in fertility in this period (Engelhardt et al. 2018). Krafft (2020) recently argued that Egypt's demographic transition is not stalling but reversing by showing that Egypt's fertility rate reached 3.5 in 2012 after reaching a low of 3.0 in 2008. Even in the first decade of the $21^{\text {st }}$ century, about 3 out of 4 MENA countries had fertility rates well above the replacement level (World Bank 2018), despite declining infant mortality rates and development progress. One explanation for these observed trends could be that the cultural and ideological innovations that triggered gender equality in Western countries were not yet present in the MENA region. Women's participation in the economy remained considerably low, while the returns of marriage for women were still high. Moghadam (2001) emphasized that the kind of development that was witnessed in the MENA countries reinforced patriarchal gender contracts in the MENA region. The idea is consistent with McDonald's (2000b: 432) proposition, which posits that " $\mathrm{t}] \mathrm{l}$ he transition from high fertility to fertility around replacement level is accompanied by an increase in gender equity within the institution of family."

To explain the low level of gender equality in the region, scholars pointed out, on the one hand, that this low level of gender equality is due to the Islamic traditions in the region (e.g., Sharabi 1992) and the poor treatment of Muslim women (Inglehart/ Norris 2003; Landes/Landes 2001). On the other hand, Ross (2008) argued that low female employment and gender equality and high fertility are not solely due to Islamic traditions, but to structural opportunities. He pointed to the oil revenue-based economies in the region that triggered a shift from export-oriented sectors such as agriculture and manufacturing to non-export-oriented sectors such as construction and retail. Subsequently, economic growth in the region was mainly generated by flows from oil-producing countries. While oil-producing countries mainly comprise the Gulf Cooperation Council (GCC) countries, other countries benefitted indirectly from oil through remittances from migrant labourers and shared the characteristics of a rentier economy (World Bank 2013).

Historically, authoritarian regimes provided public sector jobs and the MENA region had one of the largest public sectors in the world (Amin et al. 2012). Nevertheless, with this type of economic growth a growing fiscal burden of 
an oversized public sector emerged that affected budgetary sustainability and prompted calls for downsizing and cuts in the public sector (Assaad/Barsoum 2019). For instance, the pause in public sector hiring began in Egypt in the 1970s and the share of public sector employment in total employment declined from about 35 percent in 2002 to about 20 percent in 2018 (Assaad/Barsoum 2019). Accordingly, the public sector share in hiring new entrants has fallen steadily in most MENA countries, despite progress in educational attainment and development.

Women in particular prefer public sector employment to the private sector in most MENA countries. There are several reasons for this, including the fact that public sector jobs are more hospitable and offer favourable and flexible working conditions such as short working hours, job security and social benefits (Barsoum 2016). Considering the norms that prioritize women's domestic responsibilities, such characteristics make public sector jobs more popular among women than men (Barsoum 2019). As a result, despite the feminized public sector, women's employment opportunities have been negatively impacted as public sector jobs that traditionally employed women have declined and private-sector jobs dominated in many MENA countries (Assaad/Krafft 2015). These emerging jobs in the private sector such as construction require physical strength and are dominated by men. Even the other economic pillars of the private sector that do not require physical strength are significantly dominated by men. For instance, in 2020, less than 9 percent of the tourism labour force was women in the MENA region (UNWTO 2020). This mismatch between women's rising educational attainment and stagnant labour force participation rates has been termed the "MENA paradox" (Assaad et al. 2020). As a result, women's structural opportunities have not increased despite economic growth. Overall, the fertility-development nexus in MENA countries may show different patterns than in Western countries if progress towards development is not complemented by gender equality.

\section{$3 \quad$ Data}

We include time series of 19 MENA and 24 Western countries in our analyses. As there is no standardized list, we include those that are generally referred to as MENA countries: Algeria, Bahrain, Egypt, Iran, Iraq, Jordan, Kuwait, Lebanon, Libya, Morocco, Oman, Qatar, Saudi Arabia, Sudan, Syria, Tunisia, Turkey, United Arab Emirates (UAE) and Yemen. ${ }^{2}$ Western countries refer to the countries included by Myrskylä et al. (2009): Australia, Austria, Belgium, Canada, Denmark, Finland, France, Germany, Greece, Iceland, Ireland, Israel, Italy, Japan, Luxembourg, the Netherlands, New Zealand, Norway, South Korea, Spain, Sweden, Switzerland, the United Kingdom and the United States of America (USA).

2 Iran and Turkey are included among MENA countries, given that they are located in the Middle East and share similar structural (i.e., type of economy) and cultural (i.e., religion) characteristics. Yet, as a robustness check, we only considered countries where Arabic is the official language. Findings are reported in the Appendix, Table A2. 
We use HDI data from the International Human Development Indicators database (UNDP 2019). It contains information on $\mathrm{HDI}$ and its components annually between 1990 and 2018. We use the revised version of HDI in which the calculation method was changed to the geometric mean. The HDI revision provides consistent measurements that are comparable over time and this time consistent index included: (i) gross domestic product (GDP) per capita at purchasing power parity (PPP) referring to the standard of living, (ii) average of the adult literacy rate and the combined primary, secondary and tertiary gross school enrolment ratio referring to the human capital endowment and (iii) annual life expectancy at birth, referring to the health component of development.

Fertility data, which is available yearly between 1960 and 2018, comes from the World Development Indicators (WDI; World Bank 2018). It is measured by the country-specific annual total fertility rate reflecting the number of children that would be born to a woman during the considered age window if she experienced the agespecific fertility rates observed in a particular year. The main weakness of the TFR is that it is subject to tempo effects of fertility (Bongaarts/Feeney 1998; Sobotka/ Lutz 2011). Tempo adjusted fertility measures may provide a more comprehensive overview of the fertility trends and may (partly) explain changing TFR (Bongaarts/ Sobotka 2012). Yet fertility changes in MENA countries differ greatly from those in advanced societies (see Balbo et al. 2013 for a review of fertility in advanced societies). Age-specific fertility rates have not experienced a shift to the right in most MENA countries, suggesting that the mean age at first birth has not changed considerably in this region (Engelhardt et al. 2018). Accordingly, tempo effects are likely to be an issue only for the analysis of Western countries. While acknowledging this critique, other indicators of fertility such as age at first birth are only available in time-series data every five years between 1990 and 2015 and the TFR is the only available fertility measure for MENA countries that allows a longitudinal analysis of the fertility-development relationship. ${ }^{3}$ Moreover, it is plausible that the TFR provides extensive insight into fertility comparison between MENA and Western countries because it "is the most widely used indicator of fertility, as TFR is a key determinant of the number of children born in a calendar year and thus of population aging and population growth/decline" (Myrskylä et al. 2011: 38) and most public debates on fertility trends focus on the TFR.

\section{$4 \quad$ Method}

We estimated the relationship between fertility and development using two approaches. While the first approach focused on how the association between fertility and development varies between different periods, the overall association between

3 Nevertheless, in additional robustness checks, we replicated our models while controlling for the mean age at childbearing. Findings did not deviate strongly from the main outcomes and are reported in the Appendix. 
these two indicators was examined with the second strategy. More specifically, we first applied linear regression models with fixed effects at country-level separately for MENA and Western countries to examine the relationship between fertility and development with the following formula using time-series annual data:

$$
T F R_{t c}=\alpha+\beta H D I_{t c}+\gamma_{c}+\varepsilon_{t c}
$$

where $t$ indicated the year and $c$ the country. The terms $\gamma_{c}$ represented time invariant country-specific effects, which are accounted for with country fixed effects and $\varepsilon_{t c}$ is the error term. To examine how the fertility-development link evolved since 1990 , we compared the estimated coefficients of $\mathrm{HDI}(\beta)$ between six periods: $1990-$ 1994, 1995-1999, 2000-2004, 2005-2009, 2010-2014 and 2015-2018. We used robust standard errors clustered by country in all models to account for heteroscedasticity and deal with atypical countries.

We then examined the fertility-development link by adopting the difference estimation strategy of Myrskylä et al. (2009). Specifically, we estimated a piecewise linear model where the coefficient of HDI (or subindices of HDI and FLFP) can differ above and below a predetermined threshold value with the following equation:

$$
\Delta T F R_{c t}=\alpha \Delta B_{c t}^{\text {post }}+\beta^{\text {pre }} \Delta X_{c t}^{\text {pre }}+\beta^{\text {post }} \Delta X_{c t}^{\text {post }}+\Delta \gamma_{t}+\Delta \epsilon_{i t}
$$

where $t$ indicated the year and $c$ the country. The coefficients $\beta^{p r e}$ and $\beta^{\text {post }}$ estimated the effects of HDI on TFR above and below the threshold value, respectively. $\Delta$ referred to the difference indicator: $\Delta X_{t}=X_{t}-X_{(t-1)}$ and $\Delta X_{c t}^{\text {post }}=B_{c t}^{\text {post }} \Delta X_{i t}$. Differencing allows us to control for country fixed-effects and account for the unit root from the residual autocorrelation. $B_{c t}^{\text {pre }}$ a $\mathrm{nd} B_{c t}^{\text {post }}$ were dummy variables indicating whether the HDI was below and above threshold value, respectively. $\gamma_{t}$ denoted year-specific effects common to all countries. We tested whether there is a significant reversal in the fertility-development relationship with this specification.

To determine the threshold value, we also followed the strategy of Myrskylä et al. (2009) and used maximum likelihood methods. Equation 1 was estimated using a wide range of potential threshold values and the threshold value with the maximum log-likelihood function was used in the main analyses.

\section{$5 \quad$ Results}

As the first step of the analysis, we made a cross-country comparison of the relationship between TFR and HDI. We fitted linear and polynomial prediction plots to display cross-country associations in Figure 1-4. These predicted plots describe the cross-country associations between fertility and development at two points in time (i.e., 1990 and 2018). Panel A and B of Figure 1 plot how the linear relationship varies across Western countries in 1990 and 2018, respectively. In both periods, Western countries' fertility levels increased with development. Polynomial 
Fig. 1: Cross-country association between fertility and development (Western countries)

Panel A: 1990

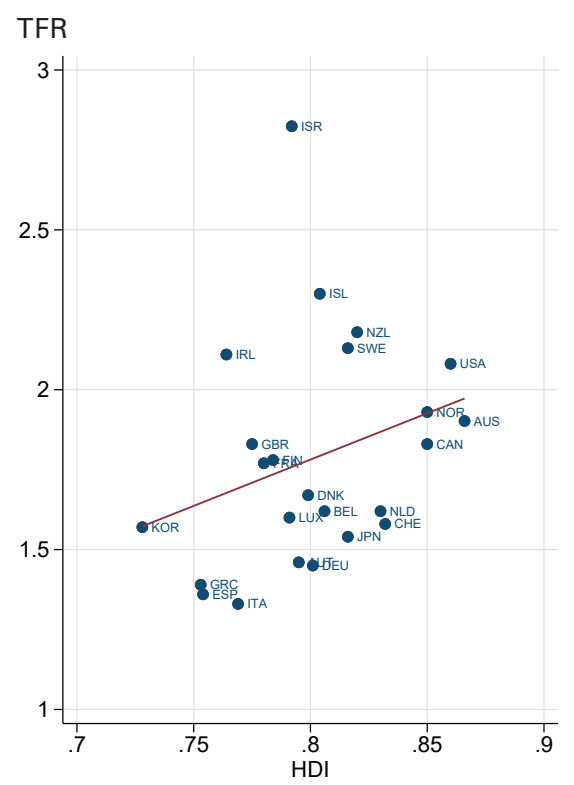

Panel B: 2018

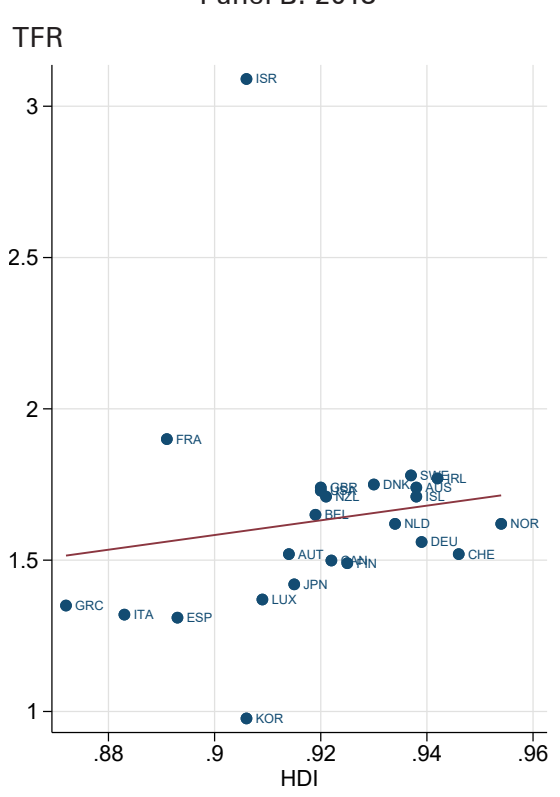

Source: UNDP (2017), World Bank (2018)

prediction plots of Western countries illustrated in Figure 2, however, imply that the positive relationship between fertility and development reversed to negative at very advanced levels of development in 2018. Yet these findings should be interpreted with caution given that the reversal is driven by a few countries.

On the contrary, cross-country analyses of MENA countries indicate that fertility declined at higher levels of development, as shown in Figure 3. The predicted polynomial plots of MENA countries, shown in Figure 4, were similar to Figure 3 with the exception that the negative relationship between fertility and development became weaker at the higher levels of development in 1990. Moreover, most MENA countries experienced notable declines in TFR between 1990 and 2018. While the average TFR of MENA countries was 4.88 in 1990, it decreased to 2.60 in 2018.

Table 1 shows the estimates of the linear regression models with country-level fixed effects. Unlike the cross-sectional analysis in Figure 1, fertility and development trends of Western countries was negative in 1990-1994. This relationship became insignificant in the next two 5 -year periods. Consistent with the recent demographic theories (Anderson/Kohler 2015; Esping-Andersen/Billari 2015; Goldscheider et al. 2015), the negative relationship between fertility and development reverses to positive in 2005-2009. This period relates to the most recent data analysed by Myrskylä et al. (2009), who found a reversal of the relationship between fertility and development from negative to positive. Yet the main findings of Myrskylä et al. (2009) disappeared when we examined the most recent periods. In fact, fertility in 
Fig. 2: Cross-country association between fertility and development with polynomial prediction plots (Western countries)

Panel A: 1990

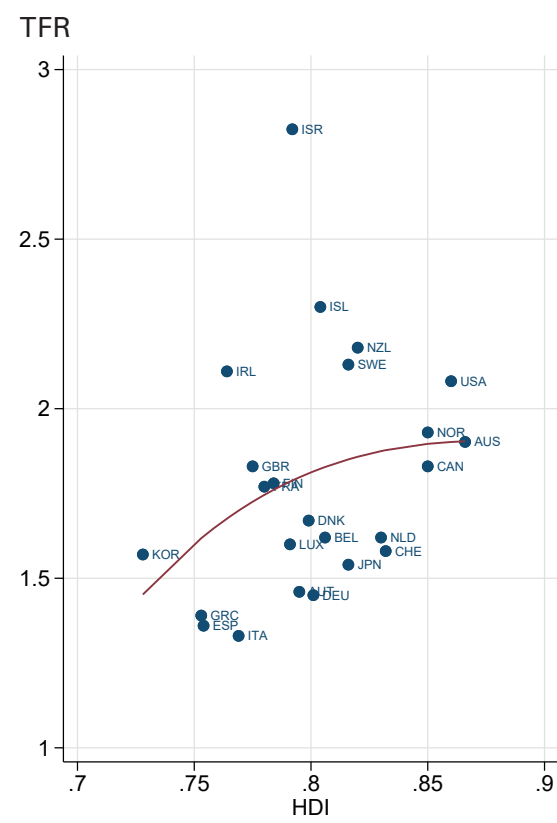

Panel B: 2018

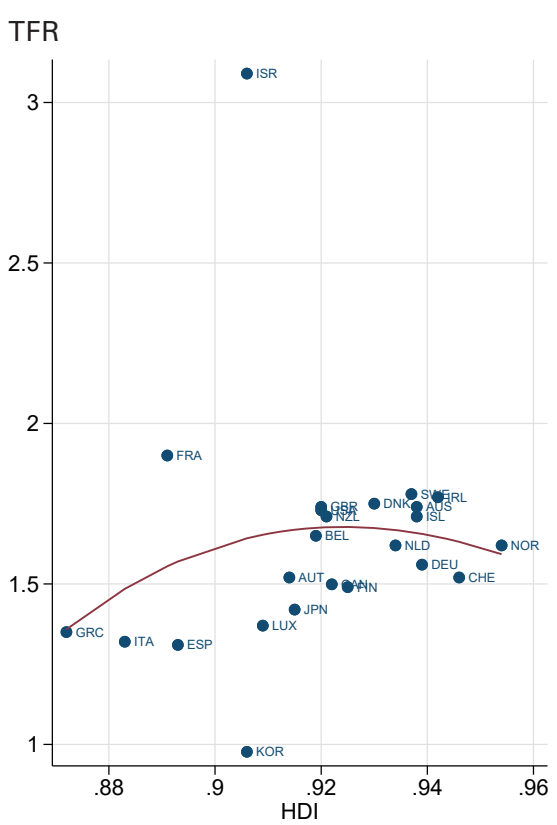

Source: UNDP (2017), World Bank (2018)

Western countries was negatively associated with development in 2010-2014 and 2015-2018. These findings suggest that the positive association between fertility and development in Western countries was temporary. In MENA countries, fertility declined significantly and noticeably at the higher levels of development between 1990 and 2004. Yet this relationship became insignificant in 2005-2009. In the subsequent periods (i.e., 2010-2014 and 2015-2018), unlike in Western countries there was also no longer a systematic relationship between fertility and development.

Tab. 1: Regression results (robust standard errors in parentheses)

\begin{tabular}{lllllll}
\hline HDI & $1990-1994$ & $1995-1999$ & $2000-2004$ & $2005-2009$ & $2010-2014$ & $2015-2018$ \\
\hline Western & $-2.416^{* *}$ & -0.966 & 0.032 & $4.404^{* *}$ & $-4.980^{* * *}$ & $-9.267^{* * *}$ \\
& $(0.753)$ & $(0.794)$ & $(0.979)$ & $(1.494)$ & $(0.986)$ & $(2.260)$ \\
\multirow{2}{*}{ MENA } & $-15.948^{* * *}$ & $-14.977^{* * *}$ & $-10.575^{* * *}$ & -3.572 & 0.830 & -2.137 \\
& $(4.456)$ & $(3.156)$ & $(2.126)$ & $(1.921)$ & $(1.402)$ & $(4.401)$ \\
\hline
\end{tabular}

${ }^{*} \mathrm{p}<0.05,{ }^{* *} \mathrm{p}<0.01,{ }^{* * *} \mathrm{p}<0.001$

Source: UNDP (2017), World Bank (2018) 
Fig. 3: Cross-country association between fertility and development (MENA countries)

Panel A: 1990

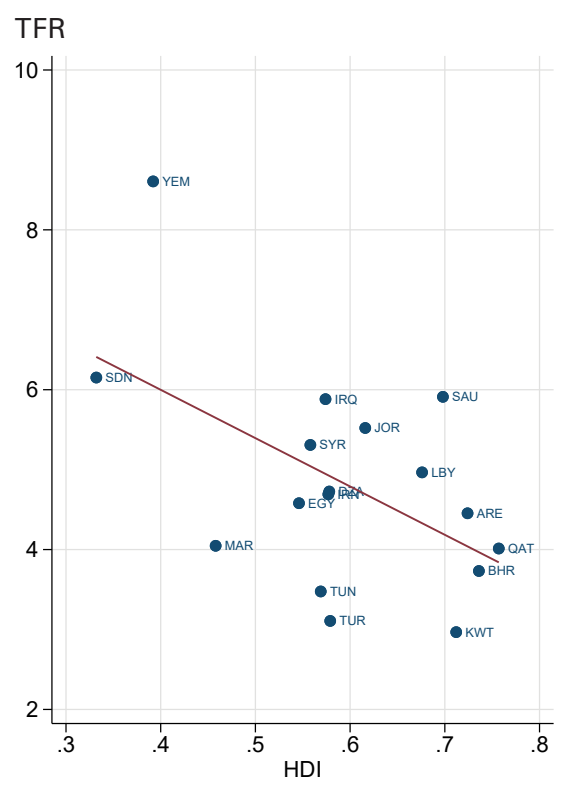

Panel B: 2018

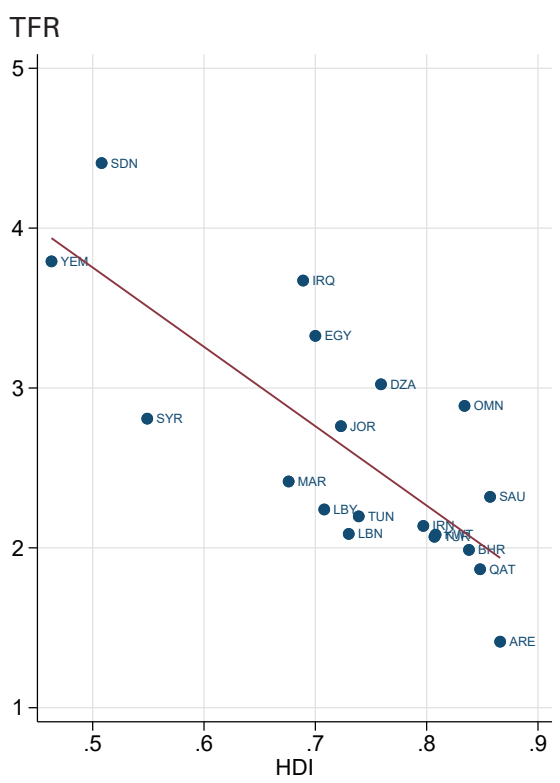

Source: UNDP (2017), World Bank (2018)

Results for the three HDI subindices and female labour force participation (FLFP) are presented in Table 2. For the education and health indices, findings are very similar to Table 1, except that the negative relationship between fertility, on the one hand, and education and health, on the other hand, became significant during the 2015-2018 period. In contrast, both Western and MENA countries' standard of living was weakly associated with fertility. ${ }^{4}$ Only in 2005-2009 - the period when the fertility-development link became positive -, were estimated coefficients of the FLFP significant for Western countries. This is in line with Luci-Greulich and Thévenon (2014), who found a positive relationship between female employment and fertility for within-country variation.

So far, we have examined how the association between TFR and HDI has changed over time. In Table 3, we adopted the difference-in-differences strategy of Myrskylä et al. (2009) and examined the overall relationship. In line with the findings of Harttgen and Vollmer (2014), the estimated threshold value of HDI was 0.808 and there was no reversal in the fertility-development link among Western countries.

4 Further analyses of MENA countries (not shown) where fertility was regressed on the three components of HDI together had illustrated that standard of living is positively associated with fertility when controlling for health and education in 2015-2018. This suggests that MENA region's insignificant association between fertility and development in 2015-2018 was related to socioeconomic development. 
Fig. 4: Cross-country association between fertility and development with polynomial prediction plots (MENA countries)

Panel A: 1990

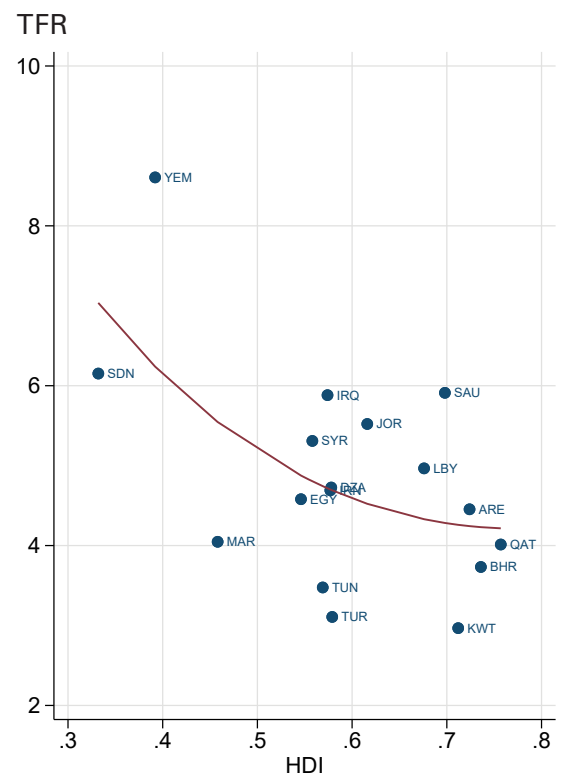

Panel B: 2018

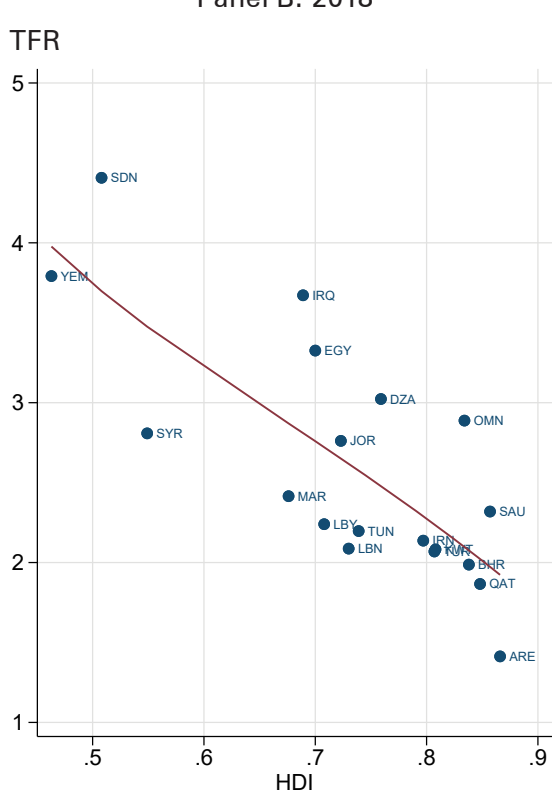

Source: UNDP (2017), World Bank (2018)

Moreover, while fertility was negatively related to education and health, standard of living was insignificantly associated with fertility in line with the findings shown in Table 2.

Findings for MENA countries showed different patterns than those for Western countries. The calculated threshold was strikingly low, suggesting that the difference-in-differences strategy of Myrskylä et al. (2009) was not well suited for the MENA region. Moreover, development was insignificantly associated with fertility below the certain threshold value we determined. Yet fertility started increasing above this threshold value. While increasing levels of education and health were negatively linked to fertility below the threshold value we identified, fertility rates were positively associated with education and health above this threshold value. Strikingly, fertility rates in MENA countries were positively related to socioeconomic development below the determined threshold value. For both Western and MENA countries, the overall relationship between fertility and FLFP was negative above the determined threshold value.

To strengthen confidence in our findings, we performed several additional analyses including controlling for mean age at childbearing, focusing only on Arabicspeaking countries, using quinquennial fertility data, inclusion of a quadratic term and replicating the first model by focusing on 10 - and 15 -year intervals. Findings were qualitatively robust to these specifications and are reported in the Appendix. 
Tab. 2: Regression models with HDI components and FLFP rates (robust standard errors in parentheses)

\begin{tabular}{|c|c|c|c|c|c|c|}
\hline & 1990-1994 & 1995-1999 & $2000-2004$ & $2005-2009$ & 2010-2014 & $2015-2018$ \\
\hline \multicolumn{7}{|c|}{ Panel A: Education } \\
\hline Western & $\begin{array}{l}-1.196^{* *} \\
(0.326)\end{array}$ & $\begin{array}{l}-0.463 \\
(0.458)\end{array}$ & $\begin{array}{l}-0.022 \\
(0.382)\end{array}$ & $\begin{array}{c}1.579 * \\
(0.736)\end{array}$ & $\begin{array}{l}-2.145^{* *} \\
(0.533)\end{array}$ & $\begin{array}{l}-6.818^{* *} \\
(2.038)\end{array}$ \\
\hline MENA & $\begin{array}{l}-10.238^{* *} \\
(3.457)\end{array}$ & $\begin{array}{l}-9.215^{*} \\
(3.141)\end{array}$ & $\begin{array}{l}-7.176^{* * *} \\
(1.259)\end{array}$ & $\begin{array}{l}-1.888 \\
(1.031)\end{array}$ & $\begin{array}{r}0.200 \\
(0.975)\end{array}$ & $\begin{array}{l}-4.639 * * * \\
(0.682)\end{array}$ \\
\hline \multicolumn{7}{|c|}{ Panel B: Standard of living } \\
\hline Western & $\begin{array}{l}-0.931 \\
(1.564)\end{array}$ & $\begin{array}{r}-1.277 \\
(0.990)\end{array}$ & $\begin{array}{r}0.638 \\
(2.598)\end{array}$ & $\begin{array}{r}0.304 \\
(1.416)\end{array}$ & $\begin{array}{r}-2.345 \\
(2.539)\end{array}$ & $\begin{array}{l}-6.182^{* *} \\
(1.709)\end{array}$ \\
\hline MENA & $\begin{array}{r}-2.111 \\
(1.603)\end{array}$ & $\begin{array}{l}-7.970^{* *} \\
(2.271)\end{array}$ & $\begin{array}{r}-1.511 \\
(2.465)\end{array}$ & $\begin{array}{l}-2.353 \\
(2.223)\end{array}$ & $\begin{array}{r}0.886 \\
(0.751)\end{array}$ & $\begin{array}{r}1.747 \\
(1.191)\end{array}$ \\
\hline \multicolumn{7}{|c|}{ Panel C: Health } \\
\hline Western & $\begin{array}{l}-4.227^{*} \\
(1.752)\end{array}$ & $\begin{array}{l}-2.449 \\
(1.364)\end{array}$ & $\begin{array}{l}-0.050 \\
(1.545)\end{array}$ & $\begin{array}{l}6.124^{* * *} \\
(1.079)\end{array}$ & $\begin{array}{l}-7.572 * * * \\
(1.545)\end{array}$ & $\begin{array}{l}-9.991 * * * \\
(2.395)\end{array}$ \\
\hline MENA & $\begin{array}{l}-26.570^{* * *} \\
(3.071)\end{array}$ & $\begin{array}{l}-25.713^{* * *} \\
(5.007) \\
\end{array}$ & $\begin{array}{l}-12.642^{* * *} \\
(2.691)\end{array}$ & $\begin{array}{r}-4.296 \\
(3.333) \\
\end{array}$ & $\begin{array}{r}-0.196 \\
(3.826) \\
\end{array}$ & $\begin{array}{l}-7.567^{* *} \\
(2.217)\end{array}$ \\
\hline \multicolumn{7}{|c|}{ Panel D: FLFP } \\
\hline Western & $\begin{array}{l}-0.005 \\
(0.010)\end{array}$ & $\begin{array}{r}0.004 \\
(0.005)\end{array}$ & $\begin{array}{r}0.007 \\
(0.006)\end{array}$ & $\begin{array}{l}0.032^{* *} \\
(0.009)\end{array}$ & $\begin{array}{l}-0.015 \\
(0.014)\end{array}$ & $\begin{array}{l}-0.025 \\
(0.018)\end{array}$ \\
\hline MENA & $\begin{array}{c}-0.092 \\
(0.080)\end{array}$ & $\begin{array}{l}-0.076 \\
(0.061)\end{array}$ & $\begin{array}{r}-0.016 \\
(0.042)\end{array}$ & $\begin{array}{r}-0.012 \\
(0.023)\end{array}$ & $\begin{array}{l}-0.009 \\
(0.020)\end{array}$ & $\begin{array}{r}0.022 \\
(0.016)\end{array}$ \\
\hline
\end{tabular}

${ }^{*} \mathrm{p}<0.05,{ }^{* *} \mathrm{p}<0.01,{ }^{* * *} \mathrm{p}<0.001$

Source: UNDP (2017), World Bank (2018)

\section{Conclusion}

In this study, we examined the association between fertility and development among Western and MENA countries. The main contribution of the present study is twofold. First, we showed that well-established theories of fertility and development may not apply in every context. While fertility and development have been negatively associated in Western countries in recent years, there was no significant relationship in MENA countries during the same period. Indeed, further analyses where we focused on the overall relationship rather than specific periods implied that fertility and development is positively associated above the identified threshold. A separate examination of the HDI components suggested that this association was mainly related to the standard of living component. These findings of MENA countries are in line with McDonald (1994) and McNicoll (1980) who emphasize that the process of social change may not be the same across all societies and may be influenced by cultural and institutional contexts. 
Tab. 3: Regression results: Difference-in-differences (standard errors in parentheses)

\begin{tabular}{lccccc}
\hline \multicolumn{1}{l}{ HDI } & Education & Standard of living & Health & FLFP \\
\hline Western & & & & \\
Pre & -0.656 & -0.017 & 1.070 & -1.332 & 0.000 \\
& $(0.976)$ & $(0.448)$ & $(2.042)$ & $(2.762)$ & $(0.003)$ \\
Post & $-1.093^{*}$ & $-0.390^{*}$ & -0.231 & $-4.784^{*}$ & $-0.024^{* *}$ \\
& $(0.446)$ & $(0.161)$ & $(0.472)$ & $(1.873)$ & $(0.008)$ \\
Threshold value & 0.808 & 0.716 & 0.806 & 0.866 & 0.737 \\
\hline MENA & & & & \\
Pre & 0.059 & $-1.583^{*}$ & $3.657^{* * *}$ & $-5.581^{* * *}$ & 0.003 \\
& $(0.571)$ & $(0.806)$ & $(0.902)$ & $(1.518)$ & $(0.005)$ \\
Post & $1.604^{*}$ & $0.541^{*}$ & 0.230 & $2.745^{*}$ & $-0.022^{* * *}$ \\
& $(0.628)$ & $(0.260)$ & $(0.207)$ & $(1.060)$ & $(0.005)$ \\
Threshold value & 0.675 & 0.383 & 0.478 & 0.775 & 0.416 \\
\hline
\end{tabular}

${ }^{*} \mathrm{p}<0.05,{ }^{* *} \mathrm{p}<0.01,{ }^{* * *} \mathrm{p}<0.001$

Source: UNDP (2017), World Bank (2018)

Secondly, our analyses focusing on Western countries have shown that the relationship between fertility and development were significantly positive for a short period (i.e., 2005-2009), yet afterwards the relationship became negative again. Moreover, analyses where we employed the difference-in-differences strategy of Myrskylä et al. (2009) indicated no reversal from negative to positive in the fertility-development link. Accordingly, we found no empirical evidence supporting recent demographic theories that suggest a reversal from negative to positive in the fertility-development link (Anderson/Kohler 2015; Esping-Andersen/ Billari 2015; Goldscheider et al. 2015). Furthermore, the difference-in-differences strategy implied that the overall association between fertility and female labour force participation was negative among both Western and MENA countries above the threshold value we determined. Yet these findings should be interpreted with caution because we observed no significantly negative relationships in the analyses where we focused on how this relationship changed over time in both Western and MENA countries. Moreover, the identified threshold for MENA countries was considerably low, suggesting that the strategy of Myrskylä et al. (2009) is not particularly compatible.

We conclude with limitations and suggestions for further research. TFR is used to measure fertility throughout the analyses. Yet TFR is an imperfect measure given that it is affected by the timing of childbearing and both Western and MENA countries have experienced notable shifts in age of first childbirth (Bongaarts 1999). At the same time, union formation was postponed in the MENA region in the 2000s together with development, resembling the nuptiality patterns of the Western world in the 1970s (Kuhn 2012; Ortega 2014). Moreover, evidence indicates that no 
marriage regime has been able to reduce fertility in the MENA region (Engelen/ Puschmann 2011). Given that childbearing is mostly within marriage in MENA countries, fertility could be reduced due to the postponement of marriages among younger generations, leading to rebounds in the latter period. Accordingly, we note that TFR could not capture these trends. However, additional analyses where we controlled for timing of childbearing supported our main findings, although these findings should be interpreted cautiously due to limited available data on the timing of childbearing. Moreover, annual UN data on TFR is primarily based on a later interpolation of the quinquennial base data in most developing countries. Thereby, there could be less variability in TFR among MENA countries leading to biased standard errors. To acknowledge this, we replicated our analyses using the original quinquennial fertility data as a robustness check.

We assumed that development affects fertility in the analyses. Yet the effects could work in both directions: Fertility may affect development. We also expected that the fertility-development link of MENA countries is different from Western countries due to the distinct progress and evolution of gender equality in the region. Indeed, fertility-development trends of MENA countries are noticeably different from findings on Western countries (Fox et al. 2019; Myrskylä et al. 2009, 2011) and theoretical expectations (Anderson/Kohler 2015; Esping-Andersen/Billari 2015; Goldscheider et al. 2015). Consequently, there could be factors such as barriers in the use of contraception, problems in women's reconciliation of work and family life or unwanted fertility affecting these trends. These factors are not tested in this study. Why MENA countries show different fertility trends and have not become more gender-equal societies with increasing levels of development is beyond the scope of this paper and it would be interesting to elicit the drivers such as religion and/or structural opportunities of this trend. In conclusion, future research may elicit the drivers of a positive fertility-development link among Western countries that only emerged for a short period.

\section{References}

Amin, Magdi et al. 2012: After the Spring: Economic Transitions in the Arab World. Oxford University Press. https://doi.org/10.1093/acprof:oso/9780199924929.001.0001

Anderson, Thomas; Kohler, Hans-Peter 2015: Low Fertility, Socioeconomic Development, and Gender Equity. In: Population and Development Review 41,3: 381-407. https://doi.-org/10.1111/j.1728-4457.2015.00065.x

Assaad, Ragui; Barsoum, Ghada 2019: Public employment in the Middle East and North Africa. In: IZA World of Labor 463. https://doi.org/10.15185/izawol.463

Assaad, Ragui et al. 2020: Explaining the MENA paradox: Rising educational attainment yet stagnant female labor force participation. In: Demographic Research 43: 817-850. https://doi.org/10.4054/DemRes.2020.43.28

Assaad, Ragui; Krafft, Caroline (Eds.) 2015: The Egyptian Labor Market in an Era of Revolution. Oxford University Press. https://doi.org/10.1093/acprof:oso/9780198737254.001.0001 
Balbo, Nicoletta; Billari, Francesco C.; Mills, Melinda 2013: Fertility in Advanced Societies: A Review of Research. In: European Journal of Population / Revue Européenne de Démographie 29,1: 1-38. https://doi.org/10.1007/s10680-012-9277-y

Barsoum, Ghada 2016: The Public Sector as the Employer of Choice among Youth in Egypt: The Relevance of Public Service Motivation Theory. In: International Journal of Public Administration 39,3: 205-215. https://doi.org/10.1080/01900692.2015.1004082

Barsoum, Ghada 2019: 'Women, work and family': Educated women's employment decisions and social policies in Egypt. In: Gender, Work \& Organization 26;7: 895-914. https://doi.org/10.1111/gwao.12285

Becker, Gary S. 1960: An Economic Analysis of Fertility. In: Universities-National Bureau (Ed.): Demographic and Economic Change in Developed Countries. New York, NY: Columbia University Press: 209-240.

Becker, Gary S. 1974: A Theory of Marriage: Part II. In: Journal of Political Economy 82,2: S11-S26. https://doi.org/10.1086/260287

Bel Air, Françoise de 2017: Fertility and marriage in the Middle East: Paradoxical trends. Orient XXI [https://orientxxi.info/magazine/fertility-and-marriage-in-the-middle-eastparadoxical-trends,1894, 12.07.2021].

Bongaarts, John 1999: The fertility impact of changes in the timing of childbearing in the developing world. In: Population Studies 53,3: 277-289. https://doi.org/10.1080/00324720308088

Bongaarts, John; Feeney, Griffith 1998: On the Quantum and Tempo of Fertility. In: Population and Development Review 24,2: 271-291. https://doi.org/10.2307/2807974

Bongaarts, John; Sobotka, Tomáš 2012: A Demographic Explanation for the Recent Rise in European Fertility. In: Population and Development Review 38,1: 83-120. https://doi.org/10.1111/j.1728-4457.2012.00473.x

Caldwell, John C. 1982: Theory of fertility decline. London: Academic Press.

Corsini, Carlo A.; Viazzo, Pier Paolo 1993: The decline of infant mortality in Europe, 1800-1950: four national case studies. Historical Perspectives 2. International Child Development Centre: Florence.

Davis, Kingsley 1945: The World Demographic Transition. In: The ANNALS of the American Academy of Political and Social Science 237,1: 1-11. https://doi.org/10.1177/000271624523700102

Derosas, Renzo; van Poppel, Frans (Eds.) 2006: Religion and the Decline of Fertility in the Western World. Dordrecht: Springer. https://doi.org/10.1007/1-4020-5190-5

Engelen, Theo; Puschmann, Paul 2011: How unique is the Western European marriage pattern? A comparison of nuptiality in historical Europe and the contemporary Arab world. In: The History of the Family 16,4: 387-400. https://doi.org/10.1016/j.hisfam.2011.07.004

Engelhardt, Henriette; Schulz, Florian; Büyükkececi, Zafer 2018: Demographic and Human Development in the Middle East and North Africa. Bamberg: University of Bamberg Press. https://doi.org/10.20378/irbo-50993

Esping-Andersen, Gøsta 2009: Incomplete Revolution: Adapting Welfare States to Women's New Roles. Cambridge: Polity Press.

Esping-Andersen, Gøsta; Billari, Francesco C. 2015: Re-theorizing Family Demographics. In: Population and Development Review 41,1: 1-31. https://doi.org/10.1111/j.1728-4457.2015.00024.x 
Forsythe, Nancy; Korzeniewicz, Roberto Patricio; Durrant, Valerie 2000: Gender Inequalities and Economic Growth: A Longitudinal Evaluation. In: Economic Development and Cultural Change 48,3: 573-617. https://doi.org/10.1086/452611

Fox, Jonathan; Klüsener, Sebastian; Myrskylä, Mikko 2019: Is a Positive Relationship Between Fertility and Economic Development Emerging at the Sub-National Regional Level? Theoretical Considerations and Evidence from Europe. In: European Journal of Population 35,3: 487-518. https://doi.org/10.1007/s10680-018-9485-1

Furuoka, Fumitaka 2009: Looking for a J-shaped development-fertility relationship: Do advances in development really reverse fertility declines? In: Economics Bulletin 29,4: 3067-3074.

Goldin, Claudia 1990: Understanding the Gender Gap: An Economic History of American Women. New York, NY: Oxford University Press.

Goldin, Claudia 2006: The Quiet Revolution That Transformed Women's Employment, Education, and Family. In: American Economic Review 96,2: 1-21. https://doi.org/10.1257/000282806777212350

Goldscheider, Frances; Bernhardt, Eva; Lappegård, Trude 2015: The Gender Revolution: A Framework for Understanding Changing Family and Demographic Behavior. In: Population and Development Review 41,2: 207-239. https://doi.org/10.1111/j.17284457.2015.00045.x

Guinnane, Timothy W. 2011: The Historical Fertility Transition: A Guide for Economists. In: Journal of Economic Literature 49,3: 589-614. https://doi.org/10.1257/jel.49.3.589

Harttgen, Kenneth; Vollmer, Sebastian 2014: A Reversal in the Relationship of Human Development With Fertility? In: Demography 51,1: 173-184. https://doi.org/10.1007/s13524-013-0252-y

Inglehart, Ronald; Baker, Wayne E. 2000: Modernization, Cultural Change, and the Persistence of Traditional Values. In: American Sociological Review 65,1: 19 https://doi.org/10.2307/2657288

Inglehart, Ronald; Norris, Pippa 2003: The True Clash of Civilizations. In: Foreign Policy 135: 63-70. https://doi.org/10.2307/3183594

Kirk, Dudley 1996: Demographic Transition Theory. In: Population Studies 50,3: 361-387. https://doi.org/10.1080/0032472031000149536

Kolk, Martin 2019: Weak support for a U-shaped pattern between societal gender equality and fertility when comparing societies across time. In: Demographic Research 40,2: 27-48. https://doi.org/10.4054/DemRes.2019.40.2

Krafft, Caroline 2020: Why is fertility on the rise in Egypt? The role of women's employment opportunities. In: Journal of Population Economics 33,4: 1173-1218. https://doi.org/10.1007/s00148-020-00770-w

Kuhn, Randal/ 2012: On the Role of Human Development in the Arab Spring. In: Population and Development Review 38,4: 649-683. https://doi.org/10.1111/j.1728-4457.2012.00531.x

Landes, David S.; Landes, Richard 2001: Girl Power. In: New Republic.

Lesthaeghe, Ron 1983: A Century of Demographic and Cultural Change in Western Europe: An Exploration of Underlying Dimensions. In: Population and Development Review 9,3: 411-435. https://doi.org/10.2307/1973316

Lesthaeghe, Ron 2010: The Unfolding Story of the Second Demographic Transition. In: Population and Development Review 36,2: 211-251. https://doi.org/10.1111/j.1728-4457.2010.00328.x 
Luci-Greulich, Angela; Thévenon, Olivier 2014: Does Economic Advancement 'Cause' a Re-increase in Fertility? An Empirical Analysis for OECD Countries (1960-2007). In: European Journal of Population 30,2: 187-221. https://doi.org/10.1007/s10680-013-9309-2

Mason, Karen Oppenheim 1997: Explaining Fertility Transitions. In: Demography 34,4: 443-454. https://doi.org/10.2307/3038299

McDonald, Peter 1994: Families in developing countries: Idealized morality and theories of family change. In: Cho, Lee-Jay; Yada, Moto (Eds.): Tradition and Change in the Asian Family. Honolulu: East-West Center: 19-28.

McDonald, Peter 2000a: Gender equity, social institutions and the future of fertility. In: Journal of the Australian Population Association 17,1: 1-16. https://doi.org/10.1007/BF03029445

McDonald, Peter 2000b: Gender Equity in Theories of Fertility Transition. In: Population and Development Review 26,3: 427-439. https://doi.org/10.1111/j.1728-4457.2000.00427.x

McNicoll, Geoffrey 1980: Institutional Determinants of Fertility Change. In: Population and Development Review 6,3: 441-462. https://doi.org/10.2307/1972410

Moghadam, Valentine M. 2001: Feminism and Islamic Fundamentalism: A Secularist Approach. In: Journal of Women's History 13,1: 42-45. https://doi.org/10.1353/jowh.2001.0029

Myrskylä, Mikko; Kohler, Hans-Peter; Billari, Francesco C. 2009: Advances in development reverse fertility declines. In: Nature 460(7256): 741-743. https://doi.org/10.1038/nature08230

Myrskylä, Mikko; Kohler, Hans-Peter; Billari, Francesco C. 2011: High development and fertility: fertility at older reproductive ages and gender equality explain the positive link. In: MPIDR Working Paper WP-2011-017. https://doi.org/10.4054/MPIDR-WP-2011-017

Notestein, Frank W. 1945: Population - The Long View. In: Schultz, Theodore W. (Ed.): Food for the World. Chicago: University of Chicago Press: 36-57.

Ortega, José Antonio 2014: A Characterization of World Union Patterns at the National and Regional Level. In: Population Research and Policy Review 33,2: 161-188. https://doi.org/10.1007/s11113-013-9301-x

Population Reference Bureau 2007: New Fertility Rates for Europe [https://www.prb. org/newfertilityrates/, 11.01.2021].

Reher, David Sven 1998: Family Ties in Western Europe: Persistent Contrasts. In: Population and Development Review 24,2: 203-234. https://doi.org/10.2307/2807972

Reher, David Sven 2021: The Aftermath of the Demographic Transition in the Developed World: Interpreting Enduring Disparities in Reproductive Behavior. In: Population and Development Review 47,2: 475-503. https://doi.org/10.1111/padr.12266

Reher, David Sven et al. 2017: Agency in Fertility Decisions in Western Europe During the Demographic Transition: A Comparative Perspective. In: Demography 54,1: 3-22. https://doi.org/10.1007/s13524-016-0536-0

Rindfuss, Ronald R.; Brewster, Karin L. 1996: Childrearing and Fertility. In: Population and Development Review 22: 258-289. https://doi.org/10.2307/2808014

Ross, Michael L. 2008: Oil, Islam, and Women. In: American Political Science Review 102,1: 107-123. https://doi.org/10.1017/S0003055408080040

Roudi, Farzaneh 2001: Population trends and challenges in the Middle East and North Africa. Washington, DC: Population Reference Bureau. 
Sharabi, Hisham B. 1992: Neopatriarchy: A Theory of Distorted Change in Arab Society. New York, NY: Oxford University Press.

Sobotka, Tomáš; Lutz, Wolfgang 2011: Misleading Policy Messages Derived from the Period TFR: Should We Stop Using It? In: Comparative Population Studies 35,3: https://doi.org/10.12765/CPoS-2010-15

Tabutin, Dominique; Schoumaker, Bruno 2005: La démographie du monde arabe et du Moyen-Orient des années 1950 aux années 2000. In: Population 60,5: 611-724. https://doi.org/10.3917/popu.505.0611

UNDP 2019: Human development report 2019: Beyond income, beyond averages, beyond today: inequalities in human development in the 21st century. New York, NY: United Nations Development Programme.

UNWTO (World Tourism Organization) 2020: Regional Report on Women in Tourism in the Middle East. Madrid: UNWTO. https://doi.org/10.18111/9789284422371

Van De Kaa, Dirk J. 1987: Europe's second demographic transition. In: Population Bulletin 42,1: 1-59.

World Bank 2004: Gender and Development in the Middle East and North Africa. In: The World Bank. https://doi.org/10.1596/0-8213-5676-3

World Bank (Ed.) 2013: Jobs for shared prosperity: Time for action in the Middle East and North Africa. Washington, DC: World Bank.

World Bank (Ed.) 2017: Progress towards gender equality in the Middle East and North Africa region. Washington, DC: World Bank.

World Bank 2018: World Development Indicators. Washington, DC: World Bank.

World Economic Forum 2017: The global gender gap report.

Zafer Buyukkececi ( $\varangle)$. Universität zu Köln, Institut für Soziologie und Sozialpsychologie (ISS). Cologne, Germany. E-mail: bueyuekkececi@wiso.uni-koeln.de URL: https://iss-wiso.uni-koeln.de/de/institut/personen/b/zafer-bueyuekkececi

Prof. Dr. Henriette Engelhardt. University of Bamberg, Faculty of Social Sciences, Economics, and Business Administration. Bamberg, Germany.

E-mail: henriette.engelhardt-woelfler@uni-bamberg.de URL: https://www.uni-bamberg.de/en/demografie/professorship/prof-dr-engelhardtwoelfler/ 


\section{Appendix}

\section{Additional analyses}

Table A1 presents the findings where we replicated the models focusing on 5-year intervals by considering 10- and 15-year intervals, respectively. In Table A2, we replicated the main models focusing on 5-year intervals with different specifications. In Panel A, we included only Arabic-speaking MENA countries by excluding Turkey and Iran and including Mauritania and Palestine. Although Malta has different structural and cultural characteristics than the MENA countries considered, we additionally used the World Bank definition of MENA countries and included Djibouti and Malta (not shown). In Panel B of Table A2, we examined how the TFR-HDI relationship changed in every five year between 1990 and 2015 while controlling for timing of childbearing. ${ }^{5}$ The models were replicated using quinquennial fertility data in Panel C, given that the UN's annual information on fertility is based on a later interpolation of the quinquennial base data in most developing countries. ${ }^{6}$ Using these three specifications included in Table A2, we replicated the differencein-differences models of Myrskylä et al. (2009) and findings are reported in Panel A-C of Table A3. All these models supported the conclusions drawn from the main models.

In Table A4, we estimated the non-linear time series association between fertility and development separately for Western and MENA countries by introducing a quadratic term of HDI with the following form:

$$
T F R_{t c}=\alpha+\beta_{1} H D I_{t c}+\beta_{2} H D I_{t c}^{2}+\gamma_{c}+\lambda_{t}+\varepsilon_{t c}
$$

where $t$ indicated the year and $c$ the country. The terms $\gamma_{c}$ represented countryspecific effects, $\lambda_{t}$ denoted year-specific effects common to all countries and $\varepsilon_{t c}$ is the error term. The models focused on the period between 1990 and 2018 and included country-level and period fixed effects to account for unobserved timeconstant country heterogeneity and variation in outcome over time that is not attributed to the predictors, respectively. For a better illustration of the results, we plotted the marginal effects obtained from the regression models in Figure A1. Accordingly, we present the expected instantaneous changes in the outcome as a function of a change in the main predictors. Overall, estimated results supported our main findings. While fertility insignificantly decreased at higher levels of development among Western countries, MENA countries had higher fertility rates with increasing development.

5 These findings should be interpreted with caution, given that the timing of childbearing data is available every five years for the period 1990 to 2015.

6 Information on timing of childbearing and quinquennial base data is available until 2015. Therefore, these models were not estimated for the 2015-2018 period. 
Tab. A1: Regression results focusing on 10- and 15-year periods (robust standard errors in parentheses)

\begin{tabular}{lcccc}
\hline HDI & $1990-1999$ & $1995-2004$ & $2000-2009$ & $2010-2018$ \\
\hline Western & $-2.238^{* *}$ & -0.364 & $2.472^{* *}$ & $-2.633^{*}$ \\
\multirow{2}{*}{ MENA } & $(0.735)$ & $(0.624)$ & $(0.766)$ & $(1.098)$ \\
& $-15.856^{* *}$ & $-14.134^{* * *}$ & $-7.281^{* *}$ & -0.204 \\
\hline HDI & $(4.730)$ & $(2.104)$ & $(1.934)$ & $(1.915)$ \\
\hline Western & $1990-2004$ & $1995-2009$ & $2000-2018$ & \\
\multirow{2}{*}{ MENA } & $-1.387^{*}$ & 0.982 & -0.048 & \\
& $(0.526)$ & $(0.631)$ & $(0.552)$ & \\
\hline
\end{tabular}

${ }^{*} \mathrm{p}<0.05,{ }^{* *} \mathrm{p}<0.01,{ }^{* * *} \mathrm{p}<0.001$

Source: UNDP (2017), World Bank (2018)

Tab. A2: Robustness checks focusing on 5-year periods with different specifications (robust standard errors in parentheses)

\begin{tabular}{|c|c|c|c|c|c|c|}
\hline HDI & 1990-1995 & $1995-2000$ & $2000-2005$ & $2005-2010$ & $2010-2015$ & $2015-2018$ \\
\hline \multicolumn{7}{|c|}{ Panel A: Focusing on Arabic-speaking countries } \\
\hline MENA & $\begin{array}{l}-13.267^{* *} \\
(4.014)\end{array}$ & $\begin{array}{l}-14.920 * * * \\
(3.265)\end{array}$ & $\begin{array}{l}-10.884^{* * *} \\
(2.301)\end{array}$ & $\begin{array}{r}-4.642 \\
(2.432)\end{array}$ & $\begin{array}{r}0.585 \\
(1.647)\end{array}$ & $\begin{array}{r}-0.170 \\
(0.199)\end{array}$ \\
\hline \multicolumn{7}{|c|}{ Pane/ B: Controlling for the timing of childbearing } \\
\hline Western & $\begin{array}{r}-1.117 \\
(1.231)\end{array}$ & $\begin{array}{r}1.497 \\
(0.991)\end{array}$ & $\begin{array}{r}1.071 \\
(1.665)\end{array}$ & $\begin{array}{r}0.571 \\
(2.017)\end{array}$ & $\begin{array}{l}-6.474^{* *} \\
(2.144)\end{array}$ & \\
\hline MENA & $\begin{array}{l}-21.106^{* * *} \\
(3.421)\end{array}$ & $\begin{array}{l}-15.812^{* * *} \\
(2.958)\end{array}$ & $\begin{array}{l}-9.798 * * * \\
(2.307)\end{array}$ & $\begin{array}{l}-1.932 \\
(2.121)\end{array}$ & $\begin{array}{r}1.297 \\
(1.752)\end{array}$ & \\
\hline \multicolumn{7}{|c|}{ Panel C: Using quinquennial fertility data } \\
\hline Western & $\begin{array}{l}-1.921^{*} \\
(0.736)\end{array}$ & $\begin{array}{l}-0.387 \\
-0.641\end{array}$ & $\begin{array}{l}2.967 * * * \\
-0.595\end{array}$ & $\begin{array}{r}0.572 \\
-0.959\end{array}$ & $\begin{array}{l}-3.985^{* * *} \\
-0.882\end{array}$ & \\
\hline MENA & $\begin{array}{l}-16.647^{* * *} \\
(2.920)\end{array}$ & $\begin{array}{l}-12.835^{* * *} \\
(1.770)\end{array}$ & $\begin{array}{l}-6.602^{*} \\
(2.506)\end{array}$ & $\begin{array}{r}-1.221 \\
(2.015)\end{array}$ & $\begin{array}{l}-0.248 \\
(1.144)\end{array}$ & \\
\hline
\end{tabular}

${ }^{*} \mathrm{p}<0.05,{ }^{*} \mathrm{p}<0.01,{ }^{* * *} \mathrm{p}<0.001$

Source: UNDP (2017), World Bank (2018) 
Tab. A3: Robustness checks with difference-in-differences strategy and different specifications (robust standard errors in parentheses)

\begin{tabular}{lccc}
\hline & $\begin{array}{c}\text { Panel A: Focusing } \\
\text { on Arabic-speaking } \\
\text { countries }\end{array}$ & $\begin{array}{c}\text { Panel B: Controlling } \\
\text { for the timing of } \\
\text { childbearing }\end{array}$ & $\begin{array}{c}\text { Panel C: Using } \\
\text { quinquennial fertility } \\
\text { data }\end{array}$ \\
\hline Western & & -0.747 & $-4.711^{*}$ \\
Pre & & $(0.888)$ & $(2.215)$ \\
& & -2.723 & 4.474 \\
Post & & $(2.758)$ & $(2.282)$ \\
Threshold value & & 0.906 & 0.823 \\
\hline MENA & & & \\
Pre & 2.041 & 6.009 & 0.759 \\
& $(1.161)$ & $(4.812)$ & $(1.396)$ \\
Post & -1.105 & -4.661 & 1.435 \\
& $(1.237)$ & $(4.910)$ & $(1.989)$ \\
Threshold & 0.4 & 0.53 & 0.6 \\
\hline
\end{tabular}

${ }^{*} \mathrm{p}<0.05, * * \mathrm{p}<0.01, * * * \mathrm{p}<0.001$

Source: UNDP (2017), World Bank (2018)

Tab. A4: Non-linear association between fertility and development (robust standard errors in parentheses)

\begin{tabular}{lrr}
\hline & Western & MENA \\
\hline HDI & 1.803 & -0.069 \\
& $(14.999)$ & $(11.556)$ \\
HDI x HDI & -2.074 & 3.128 \\
& $(8.581)$ & $(9.363)$ \\
\hline
\end{tabular}

$* \mathrm{p}<0.05, * * \mathrm{p}<0.01, * * * \mathrm{p}<0.001$

Source: UNDP (2017), World Bank (2018) 
Fig. A1: Non-linear association between fertility and development (estimated marginal effects)

Panel A: Western countries

TFR

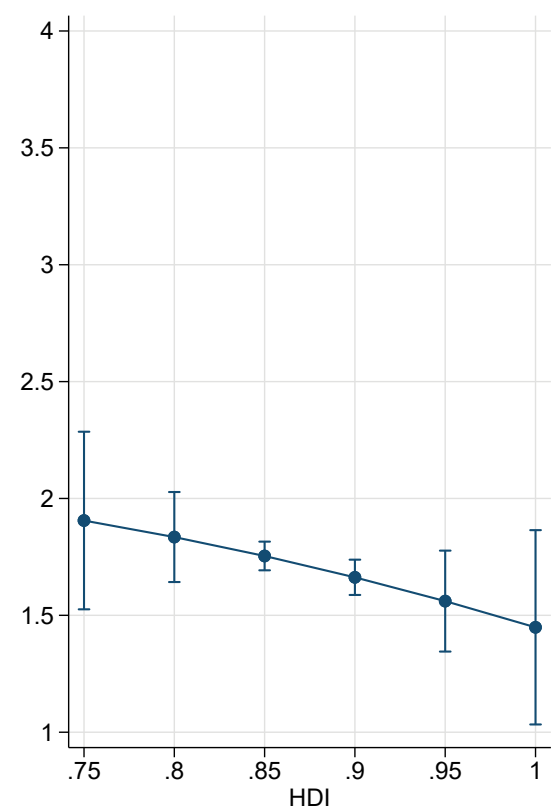

Panel B: MENA countries TFR

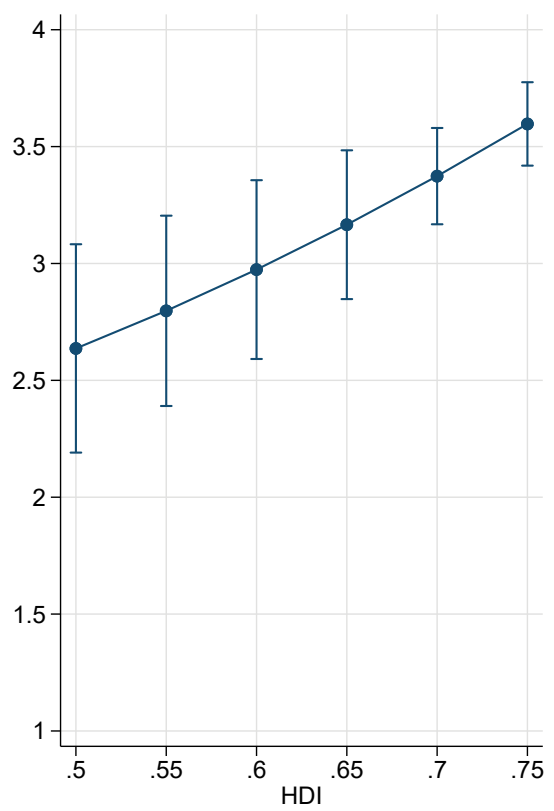

Source: UNDP (2017), World Bank (2018) 


\section{Comparative Population Studies}

WWW.comparativepopulationstudies.de

ISSN: 1869-8980 (Print) - 1869-8999 (Internet)

\section{Published by}

Prof. Dr. Norbert F. Schneider

Federal Institute for Population Research D-65180 Wiesbaden / Germany

\section{(c) BY-SA}

2021

\section{Managing Editor}

Prof. Dr. Johannes Huinink

Dr. Katrin Schiefer

\section{Editorial Assistant}

Beatriz Feiler-Fuchs

Wiebke Hamann

\section{Layout}

Beatriz Feiler-Fuchs

E-mail:cpos@bib.bund.de

\section{Scientific Advisory Board}

Karsten Hank (Cologne)

Michaela Kreyenfeld (Berlin)

Marc Luy (Vienna)

Natalie Nitsche (Rostock)

Zsolt Spéder (Budapest)

Rainer Wehrhahn (Kiel)

\section{Board of Reviewers}

Bruno Arpino (Barcelona)

Kieron Barclay (Rostock)

Laura Bernardi (Lausanne)

Gabriele Doblhammer (Rostock)

Anette Eva Fasang (Berlin)

Michael Feldhaus (Oldenburg)

Tomas Frejka (Sanibel)

Alexia Fürnkranz-Prskawetz (Vienna)

Birgit Glorius (Chemnitz)

Fanny Janssen (Groningen)

Frank Kalter (Mannheim)

Stefanie Kley (Hamburg)

Bernhard Köppen (Koblenz)

Anne-Kristin Kuhnt (Duisburg)

Hill Kulu (St Andrews)

Nadja Milewski (Wiesbaden)

Roland Rau (Rostock)

Thorsten Schneider (Leipzig)

Tomas Sobotka (Vienna)

Jeroen J. A. Spijker (Barcelona)

Heike Trappe (Rostock)

Helga de Valk (The Hague)

Sergi Vidal (Barcelona)

Michael Wagner (Cologne) 